\title{
Improving hogget performance through efficient management of the spring surplus
}

\author{
D.R. STEVENS', J.D. TURNER', S. GOWERS ${ }^{2}$, G. BAXTER' and S.D. ARMSTRONG* \\ ${ }^{1}$ AgResearch and 2 Crop and Food Research, Gore Research Station, Private Bag 50022, Gore
}

\begin{abstract}
A bstract
This paper examines how the spring management options of making silage or planting brassicas can change hogget performance. Research by Gore Research Station staff compared winter hogget growth on various winter forages including brassicas, Italian ryegrass, perennial pasture and silage from several pasture types over 5 years. Liveweight gains varied from 0 to 160 g/day for silage made from various pasture options. Specific brassicas or brassica plus Italian ryegrass combinations provided average gains of up to 146 $\mathrm{g} /$ day. The yields of forage turnips for summer and autumn use were also compared. An initial harvest of 90 days with two subsequent cuts of 30 day intervals maximised yields from the treatments examined. The combining of these spring forage management options is discussed and used to outline options which will help farmers to maximise hogget performance.
\end{abstract}

Keywords: Brassica, Cichorium intybus, hoggets, liveweight gain, Lolium multiflorum, perennial pasture, sheep, silage, summer, winter

\section{Introduction}

Introducing new pastures on-farm changes the management options available to a farmer. A greater spring surplus is created from new pasture cultivars and this in turn generates an opportunity to conserve spring forage as silage or to sow brassicas for subsequent summer or winter use. Farmers need good information to assess how these choices will impact on feed supply throughout the year and how animal performance-will be affected. Particularly important in New Zealand farming systems is the winter period when feed is in short supply. Improved winter feeding, particularly of hoggets, can benefit the whole farm operation through greater animal performance in subsequent seasons.

Winter feeding of hoggets often uses an all grass approach but generally fails to produce liveweight gains. Parratt \& Young (1983) and Wright et al. (1981) both reported liveweight losses of between 20 and $30 \mathrm{~g} /$ day, or 2-3 kg over a 100-day winter. Some gains of up to 50 g/day have been reported (Coop 1956; Drew 1967) though the potential of hoggets to grow in the winter may be as high as 226 g/day (Hickey \& Baxter 1989).

Strategies to ensure hoggets grow in winter can be based around managing spring surpluses. These surpluses can be used to provide high quality silage or reduced by using grazing areas to establish brassica crops.

This paper examines how conservation of standard or specialist pastures as silage and sowing forage brassicas to manage spring growth can be used to improve hogget performance. Recent winter animal production research findings from three trials are used to demonstrate the effectiveness of various spring management strategies.

\section{$M$ ethods}

Winter liveweight gains on silage

This trial spanned five winters from 1989 to 1993 as an on-farm trial on the property of M.B. Dillon, Nine Mile Road, Balfour. Fifty Romney cryptorchid or ewe lambs per treatment were allocated randomly to one of three treatments which included sole diets of standard pasture silage, or one of two specialist pasture silages. Standard pasture silage was made from ryegrass (Loliūm perenne), dogstail (Cynosurus cristatus), sweet vernal (Anthoxanthum oderatum), Yorkshire fog (Holcus Ianatus), browntop (A grostis stolonifera) and white clover (Trifolium repens) pasture. Specialist pasture silages were either timothy (Phleum pratense)/red clover (Trifolium pratense) or chicory (Cichorium intybus)/ hybrid ryegrass/white clover. Pastures used for silage making received $350 \mathrm{~kg} / \mathrm{ha} /$ annum high analysis fertiliser (16 8 (10 10$)$.

Standard pasture silage was used in years 1989 , 1990 and 1991. Timothy/red clover silage was tested in years 1989, 1990,1991 and 1993 and chicory/hybrid ryegrass/white clover silage was tested in 1990, 1991 and 1993. Hoggets with an average weight of between 35 and $40 \mathrm{~kg}$ were offered sole diets of silage for periods of between 31 and 70 days during the autumnwinter period. Animals were conditioned to silage by reducing grass and increasing silage intakes over 14 days piior to the measurement period and weighed 
regularly throughout the trial. Silage was fed daily in troughs to allow a 10\% refusal and residual silage was cleaned out every 3 to 4 days. Clean water was provided throughout. Hoggets were housed indoors in 1989, 1990 and 1991 and outdoors in 1991 and 1993.

Feed intakes were assessed over two days in both early and late feeding stages of each year by weighing the offered and rejected silage daily.

\section{Winter liveweight gains on brassicas and Italian ryegrass}

These trials were carried out at the Gore Research Station Farm in 1992 and 1994 and on the property of K. Spittle, Gore in 1993. Treatments were Doon Major or Tina swede (Brassica napus), Tina swede plus Grasslands Moata Italian ryegrass (Lolium multiflorum) (sown at $2 \mathrm{~kg} / \mathrm{ha}$ ), Doon Major plus rape (Brassica napus) and 2 experimental swede lines. Swedes were drilled on the flat at $13 \mathrm{~cm}$ row spacing and a seeding rate of $1 \mathrm{~kg} / \mathrm{ha}$, except when sown with rape when 0.8 $\mathrm{kg} / \mathrm{ha}$ was sown with $0.4 \mathrm{~kg} / \mathrm{ha}$ of rape.

Between 6 and 9 ewe hoggets with an average weight of 33, 39 and $35 \mathrm{~kg}$ for 1992, 1993 and 1994 respectively were allocated to either of 2 replicates of 6 treatments for a measurement period of 4 weeks in June/July. Hoggets had no conditioning in 1992 but were exposed to a Tina swedes/ryegrass mixture for 6 weeks prior to the 1993 trial and 'to kale in 1994. Weight gains were recorded at weekly intervals in 1992 just prior to shifting the hoggets onto fresh forage. In 1993 and 1994, the hoggets were given fresh forage every other day and were weighed after 2 and 4 .weeks. Dry matter intake was assessed by harvesting the total forage before grazing and then measuring the residue after grazing. All treatments were included in a standard analysis of variance but the two experimental lines are not reported here.

\section{Summer forage options}

Three replicates of 7 stubble turnip (Brassica campestris) cultivars were sown at 100 seeds $/ \mathrm{m}^{2}$ (approximately 3 $\mathrm{kg} / \mathrm{ha}$ ) at $13 \mathrm{~cm}$ row spacings. The forage turnip cultivars were Appin, Pasja, Forage Star, Rondo, AllTop, Savannah and an advanced breeding line, TAP. AllTop and Savannah were removed from subsequent analysis because of excessive premature bolting. Cultivars were sown in a randomised block design on 27 November 1990. The area had been in pasture for the previous 5 years and received $250 \mathrm{~kg} / \mathrm{ha}$ high analysis fertiliser (13 15100 ) prior to sowing and a further $50 \mathrm{~kg} \mathrm{~N} / \mathrm{ha}$ as sulphate of ammonia on 20 February 1991.

Dry matter yield was measured at intervals over the following 156 days with initial harvest time applied as a split plot to begin at either 60,90,120 or 156 days, with sequential harvesting at 30-day intervals thereafter. Plots measured $24.3 \mathrm{~m}^{2}$ with $5 \mathrm{~m}^{2}$ being harvested on all occasions. Harvesting by hand ensured all utilisable leaf was removed just above the crown.

\section{Results}

\section{Winter liveweight gains}

Silage intake in these trials did not differ significantly between treatments though it was significantly correlated to liveweight gain $(\mathrm{P}<0.05)$ (Table 1). Liveweight gain was greatest when lambs were fed chicory/hybrid ryegrass, intermediate on timothy/red clover and least on standard pasture silage. The botanical composition of the specialist silages was approximately $40 \%$ chicory $/ 40 \%$ hybrid ryegrass $/ 20 \%$ white clover and $60 \%$ timothy $/ 40 \%$ red clover.

Table 1 Liveweight gain and feed intake of hoggets fed sole silage diets during winter.

\begin{tabular}{lcccc}
\hline Silage Type & $\begin{array}{c}\text { Years of } \\
\text { D a t a }\end{array}$ & $\begin{array}{c}\text { Feeding } \\
\text { Duration } \\
\text { (Days) }\end{array}$ & $\begin{array}{c}\text { Intake } \\
\text { (kgDM/day) }\end{array}$ & $\begin{array}{c}\text { Liveweight } \\
\text { gain (g/day) }\end{array}$ \\
\hline $\begin{array}{c}\text { Standard } \\
\text { Pasture }\end{array}$ & 3 & $31-70$ & 1.2 & $44 \mathrm{~b}$ \\
$\begin{array}{c}\text { Timothy/Red } \\
\text { clover }\end{array}$ & 4 & $31-70$ & 1.3 & $04 \mathrm{ab}$ \\
$\begin{array}{c}\text { Chicory/hybrid } \\
\text { ryegrass }\end{array}$ & 3 & $40-70$ & 1.4 & $127 \mathrm{a}$ \\
Isd & & & $\mathrm{ns}$ & $\mathbf{5}$ \\
\hline
\end{tabular}

Silage quality measurements (Table 2) showed that $\mathrm{pH}$ did not differ significantly between the silages and was low, indicating a good state of preservation. The amount of $\mathrm{NH},-\mathrm{N}$, expressed as a percentage of total $\mathrm{N}$ was highest in the timothy/red clover silage, intermediate in the standard pasture silage and lowest in the chicory/ hybrid ryegrass silage. Crude protein levels were similar in' all these silages. The digestibility of the chicory/ hybrid ryegrass silage was significantly greater than the timothy/red clover silage which was greater than the digestibility of the standard pasture silage.

Table 2 The quality of the 3 silages compared in the winter feeding trials (meaned over the trial).

\begin{tabular}{lcccc}
\hline Silage type & $\mathrm{pH}$ & $\begin{array}{c}\mathrm{NH},-\mathrm{N} \\
(\% \text { of } \\
\text { total N) }\end{array}$ & $\begin{array}{c}\text { Crude } \\
\text { prote in } \\
(\% \mathrm{DM})\end{array}$ \\
\hline Standard pasture & 4.1 & $9.6 \mathrm{ab}$ & 15.2 & $67.6 \mathrm{C}$ \\
Timothy/Red clover & 4.4 & $12.5 \mathrm{a}$ & 17.0 & $71.0 \mathrm{~b}$ \\
Chicory/hybrid ryegrass & 4.0 & $6.6 \mathrm{~b}$ & 15.5 & $75.9 \mathrm{a}$ \\
Isd & $\mathrm{n} \mathrm{s}$ & 3.0 & $\mathrm{n} \mathrm{s}$ & 2.6 \\
CV\% & 5.5 & 16.3 & 13.2 & 1.9 \\
\hline
\end{tabular}


Table 3 Liveweight gain, feed intake, protein level and feed utilisation for hoggets grazing brassicas and brassica/talian ryegrass diets over two winters.

\begin{tabular}{|c|c|c|c|c|c|c|c|c|c|c|c|c|}
\hline & \multirow[t]{2}{*}{$\begin{array}{c}\text { Intake } \\
\text { (kgDM/day) }\end{array}$} & \multirow{2}{*}{$\begin{array}{l}\text { Liveweight } \\
\text { gain } \\
\text { (g/day) }\end{array}$} & \multicolumn{2}{|c|}{$\begin{array}{l}\text { Protein Levels } \\
\text { Swedes }\end{array}$} & \multirow{2}{*}{$\begin{array}{c}\text { (\% DM) } \\
\text { Grass/ } \\
\text { Rape }\end{array}$} & \multirow{2}{*}{$\begin{array}{l}\text { Utilisation } \\
\% \text { forage } \\
\text { on offer }\end{array}$} & \multicolumn{6}{|c|}{ Crop composition } \\
\hline & & & Tops & Bulbs & & & $\%$ & $\begin{array}{l}\text { Swede } \\
\text { bulb }\end{array}$ & $\%$ & $\begin{array}{l}\text { Swede } \\
\text { too }\end{array}$ & $\%$ & Grass/Rape \\
\hline $\begin{array}{l}\text { Doon Major } \\
\text { swede }\end{array}$ & $0.9 \mathrm{~b}$ & $40 \mathrm{~b}$ & 20.3 & 5.9 & & $39 \mathrm{~b}$ & & 80 & & 20 & & 0 \\
\hline Tina swede & $1.1 \mathrm{~b}$ & $109 a$ & 20.2 & 9.6 & & $55 \mathrm{a}$ & & 73 & & 27 & & 0 \\
\hline $\begin{array}{l}\text { Tina/ltalian } \\
\text { ryegrass }\end{array}$ & $1.5 \mathrm{a}$ & $132 a$ & 20.2 & 9.6 & 10.5 & $66 \mathrm{a}$ & & 56 & & 22 & & 20 \\
\hline \multirow[t]{2}{*}{$\begin{array}{l}\text { Doon } \\
\text { Major/Rape }\end{array}$} & $1.2 a b$ & $124 \mathrm{a}$ & 20.3 & 5.9 & 16.2 & $66 \mathrm{a}$ & & 49 & & 11 & & 40 \\
\hline & . & $\cdot$ & & & & t & & & & & & \\
\hline Isd & 0.35 & 26 & & & & 14 & & & & & & \\
\hline
\end{tabular}

\section{Winter liveweight gains on brassicas and Italian ryegrass}

The intake of the swede/Italian ryegrass mixture was similar. to the Swede/rape mixture and significantly higher than either swede variety alone (Table 3). Liveweight gains were greatest for the mixed forage options of swede/Italian ryegrass and Swede/rape through gains from the Tina swede were not significantly lower. The lowest gain was from the Doon Major swede (Table 3).

The protein levels (Table 3 ) in swede tops were consistent and high. Doon Major bulbs had lower protein levels than Tina bulbs. The utilisation of the forage_on_offer_(Table_3)_was_greatest_for-the-mixed forages though not significantly-greater than Tina. The utilisation of Doon Major was significantly lower than the other forages. The Doon Major had the greatest proportion of the crop as root (Table 3) and the least proportion of leaf. Tina had a greater percentage of top than Doon Major. The Italian ryegrass contributed 20\% and rape contributed $40 \%$ of the dry matter yeild. The addition of Italian ryegrass left the proportion of swede top unchanged and substitued for the swede bulb. Rape replaced both swede top, reducing it to half of the swede only crop; and swede bulb.

\section{Summer forage turnips}

Delaying the initial harvesting time to 90 days after sowing maximised the cumulative yield'though it was not significantly greater than with beginning harvesting at 60 days [Table 4). Delaying initial harvest for any longer than 90 days reduced the cumulative yield. As initial harvest time was delayed to 90 days and greater, more varieties went to seed, removing them from useful grazing.
Table 4 The influence of timing of first harvest on the summer and autumn yields of forage turnips harvested thereatter at 30-day intervals (30-day yields in brackets).

\begin{tabular}{|c|c|c|c|c|c|}
\hline \multirow[b]{2}{*}{ First cut } & & \multicolumn{4}{|c|}{ Cumulative Leaf Yield (tDM/ha) } \\
\hline & & 60 days & 90 days & 120 days & 156 days \\
\hline 60 days & $\begin{array}{c}\text { mean } \\
\text { range }\end{array}$ & $\begin{array}{c}4.1 \\
3.5-4.6\end{array}$ & $\begin{array}{c}5.9(1.6) \\
5.4-6.4\end{array}$ & $\begin{array}{c}7.0(1.1) \\
6.4-7.6\end{array}$ & $\begin{array}{c}7.3(0.3) \\
6.5-6.1\end{array}$ \\
\hline 90 days & $\begin{array}{l}\text { mean } \\
\text { range }\end{array}$ & - & $\begin{array}{c}5.9 \\
4.4-7.4\end{array}$ & $\begin{array}{c}7.4(1.5) \\
5.6-8.8\end{array}$ & $\begin{array}{c}7.7(0.3) \\
5.7-9.0\end{array}$ \\
\hline 120 days & $\begin{array}{l}\text { mean } \\
\text { range }\end{array}$ & ; & & $\begin{array}{c}4.5 \\
3.2-5.4\end{array}$ & $\begin{array}{r}5.4(0.9) \\
3.8-6.6\end{array}$ \\
\hline 156 days & $\begin{array}{l}\text { mean } \\
\text { range }\end{array}$ & & & & $\begin{array}{c}3.4 \\
2.9-4.1\end{array}$ \\
\hline SE- & & 0.74 & $1: 16$ & 1.12 & 1.13 \\
\hline
\end{tabular}

The varieties that consistently produced the highest yields were Pasja and TAP, a yet to be released experimental line. The poorest varieties which also consistently bolted were Alltop and Savannah, varieties not commercially available in New Zealand.

\section{Discussion}

The use of standard unsupplemented perennial pastures for silage produced variable and generally poor hogget liveweight gains, consistent with other New Zealand research. Marsh (1979). produced gains of between -57 and $+71 \mathrm{~g} /$ day in .lambs. Irish work also. shows variability and generally low or no gains (Fitzgerald 1986; Sheehan \& Fitzgerald 1977). These results are, however, still similar to normal hogget liveweight changes in winter (Parratt \& Young 1983; Wright et al. 1981; Coop 1956). 
The consistency of hogget liveweight gains achieved on specialist pasture silage is particularly important. Hoggets fed on specialist pasture silages achieve greater and more reliable liveweight gains than those fed on standard perennial pasture silage. The inclusion of a chicory component appears to have the greatest influence on consistency as well as producing the greatest gains. Specialist pasture silages were of higher digestibility than standard pasture silage, mainly owing to a more easily definable harvesting period. Standard pasture was too mature at harvest as seed head development was unavoidable when so many grasses are present. The average digestibility of $67.6 \%$ for the silage used in these experiments was higher than the mean silage digestibility of $63.1 \%$ found from all samples processed by the Lincoln University analytical laboratory in the first 6 months of 1993 (P. Isherwood pers. comm.).

The growth of hoggets on swedes reported here is similar to that reported by Nicol \& Barry (1980). They summarised all published NZ research from 1940 to 1977 and presented an average of 95 g/day. Nicol \& Barry (1980) highlighted a requirement for preconditioning to maximise liveweight gain, though this was not evident in these trials, as the hogget growth in 1993, when preconditioning occurred, was no greater than in 1992.

Comparative data between swede cultivars have not previously been published in New Zealand. The difference between Tina and Doon Major. was obtained in all years and may be related to the higher yield of tops and the greater protein levels in the bulbs of Tina. The difference in bulb utilisation is contrary to the general farmer opinion that sheep much prefer Doon Major to Tina. This result may be due to the preconditioning on Tina/ryegrass, but it may also be due to the sheep regulating their protein balance, which has been shown experimentally (Kyriazakis \& Oldham 1993).

The use of Italian ryegrass sown with swedes is also previously unreported and appears to be a useful mixture for winter feeding. The trial in 1992 also included Doon Major with Moata Italian ryegrass and produced a hogget liveweight gain of $118 \mathrm{~g} /$ day compared with $48 \mathrm{~g} /$ day from Doon Major alone and $180 \mathrm{~g} /$ day on Moata alone. Again a more balanced diet may be the major reason for improved hogget growth. Rape/swede mixtures also gave good liveweight gains as well as good yields. The utilisation of the whole crop increased with mixtures, particularly the utilisation of the swede bulb (S. Gowers \& S. Armstrong unpub. data).

The relative merits of various management options has been put into perspective in Figure 1 by summing hogget liveweight gains which can be theoretically achieved using the data presented here and supplied from spring liveweight gain trials (Stevens et al. unpub data). The December liveweight of $54 \mathrm{~kg}$ gained from the standard pasture system where no silage is made and spring pasture control is minimal is typical of many Southland hogget flocks (P. Hook pers. comm.). The data reported here indicate the benefits of a pasture renewal programme on subsequent two-tooth liveweight, especially when silage or other forms of late spring pasture control such as topping are introduced. The benefits of using specialist chicorybased pasture for silage in late spring further increases hogget liveweight through reliable winter liveweight gains. This outweighs a small reduction in late spring hogget growth as standard pastures are used in situ and specialist pastures ensiled. This option also provides greater flexibility, as this high quality silage can also be used to flush ewes in dry years "or feed winter contract lambs.

Figure 1 Theoretical hogget liveweight gain from combinations of winter brassica and specialist pasture options (spring growth rates from Stevens et al. unpub).

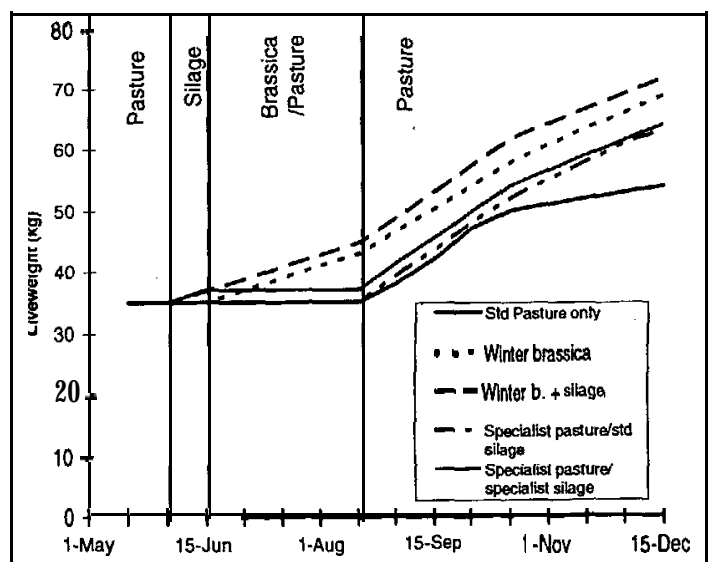

NB: Silage and Brasslca use are based on the relative expected yields from a hogget unit with $25 \%$ being closed for silage or brassicas in late spring.

Introducing brassicas can further increase both hogget liveweight and farming flexibility. Reliable winter liveweight gains can be achieved and flexibility in summer drought management is enhanced. The combination of a brassica programme and specialist pastures further adds to hogget weights. The use of summer brassicas such as stubble turnips, along with a specialist pasture renewal programme may give an intermediate result within these options while ensuring an effective drought management programme is 
maintained. The data in Table 4 show that stubble turnips can be used early and will continue growing under good grazing management. This is particularly important in areas of regular summer moisture deficit.

Additives to winter swede crops such as Italian ryegrass and rape showed that diet quality is a primary consideration to ensure that the flexibility enabled by good winter liveweight gains is maintained.

Improved lamb liveweight gains from specialist pastures has been promoted by several authors (Fraser et al. 1988; MacFarlane 1990; Brown 1990), emphasising that part of the production system. Hogget weight gains and hence two-tooth mating weights are also an area which gives a productive lift to farming. Coop (1956) drew attention to increased ewe longevity and reproductive performance due to good hogget nutrition. Using the established performance parameters of a $2 \%$ increase in lambing percentage, and $0.015 \mathrm{~kg}$ extra wool growth per kilogram of extra liveweight, then the best fed hoggets in these examples will have a $35 \%$ higher lambing and $0.26 \mathrm{~kg}$ more wool in their first year alone.

When coupled with increased ewe performance the improved hogget nutrition provided by effective management of pastures and winter forage is a major economic benefit to pastoral farmers.

\section{ACKNOWLEDGEMENTS}

Authors wish to thank Mervyn Dillon and Ken Spittle for the use of their animals, land and time; Marie Casey for her voluntary input and farm and support staff of the Gore Research Station $^{-}$for $^{-}$their $^{-}$input ${ }^{-}$into ${ }^{-}$this research.

\section{REFERENCES}

Brown, C. 1990. An integrated herbage system for Southland and South Otago. Proceedings of the New Zealand Grassland Association 52: 119-122.

Coop, I.E. 1956. The effect of high and low plane rearing of hoggets on lifetime productivity. Proceedings of the New Zealand Society of Animal Production 16: 3 1-38.
Drew, K.R. 1967. The winter nutrition of Romney hoggets. Proceedings of the New Zealand Society of Animal Production 27: 210-222.

Fitzgerald, J.J. 1986. Finishing of store lambs on silagebased diets 1. Effect of formic acid treatment or wilting and concentrate supplementation on silage intake and performance of store lambs. Irish journal of agricultural research 25: 327-345.

Fraser, T.J; Cosgrove, G.P.; Thomas, W.J.; Stevens, D.R.; Hickey, M.J. 1988. Performance of Grasslands Puna chicory. Proceedings of the New Zealand Grassland Association 49: 193-196.

Hickey, M.J.; Baxter, G.S. 1989. Winter feed value of 'Grasslands Moata' tetraploid Italian ryegrass in Southland. Proceedings of the New Zealand Grassland Association 50: 225-230.

Kyriazakis, I.; Oldham, J.D. 1993. Diet selection in sheep: the ability of growing lambs to select a diet that meets their crude protein requirements. British journal of nutrition 69: 617-629.

MacFarlane, A.W. 1990. Field experience with new pasture cultivars in Canterbury. Proceedings of the New Zealand Association 52: 139-144.

Marsh, R. 1979. The effects of wilting on fermentation in the silo and on the nutritive value of silage. Grass and forage science 34: 1 - 10.

Nicol, A.M.; Barry, T.N. 1980. The feeding of forage crops Chapter 3. In Supplementary Feeding. New Zealand Society of Animal Production Occasional Publication 7. Ed K.R. Drew and P.F. Fennessy.

Parratt, A.C.; Young M.J. 1983. Potential growth rates from birth to slaughter. Chapter 1. In Lamb Growth. Technical-Handbook--Lincoln-College-Ed-A-S. Familton.

Sheehan, W.; Fitzgerald, J.J. 1977. Effects of method of herbage conservation on performance of store lambs. Irish journal of agricultural research 16: 83-94.

Wright, D.F.; Kain, W.M.; Hamilton, G.J.; Slay M.W.A.; Luckman, M.S. 1981. Phalaris and ryegrass pastures for animal production in Hawkes Bay. Proceedings of the New Zealand Society of Animal Production 41: 119-124. 